Letter

\section{A comment on 'Take-over announcements and insider trading activity on the Johannesburg Stock Exchange'}

By studying the abnormal return behaviour of a sample of acquired firms on the Johannesburg Stock Exchange, Bhana (S.Afr.J.Bus.Mgmt. 1987, 18: 198-208) showed that shareholders of these firms earned substantial excess returns around the date of the merger announcement. Bhana showed that abnormal returns start to accumulate some $\mathbf{4 0}$ days before the first public announcement of the merger and concluded that these gains are due to insider trading or information leakage. We maintain that the methodology and tests employed by Bhana, while quantifying the abnormal returns to acquired firms' shareholders around the merger announcement, are insufficient to determine the cause of these wealth gains, and as such, Bhana's study does not prove the existence of insider trading activity on the JSE.

The approach used by Bhana follows that of Fama, Fisher, Jensen \& Roll (1969). This approach assumes that the returns on firm $j$ in time $t$ can be estimated by a linear regression model, such as Sharpe's (1963) Market Model:

$R_{j t}=\alpha_{j}+\beta R_{m t}+\epsilon_{j t}$

where $\boldsymbol{R}_{j t}=$ the return on firm $j$ in time period $t, \boldsymbol{R}_{m t}=$ return on the market in the same time period $t ; \beta_{i}=$ the systematic risk of firm $j ; \alpha_{j}=a$ constant; and $\epsilon_{j t}=a$ stochastic error term with expected value 0 , constant variance and the $\epsilon_{j i}$ 's are independent over time.

The market model is estimated over a period which does not include the merger period, and then used to compute the estimated return over the merger period. The difference between the observed and the estimated return is the so-called abnormal return. Thus:

$A R_{j t}=R_{j t}-\left(\hat{\alpha}_{j}+\hat{\beta}_{j} R_{m i}\right)$

where $A R_{j t}=$ abnormal return for firm $j$ in time period $t$, $\hat{\alpha}_{j}$ and $\hat{\beta}_{j}=$ the ordinary least squares estimates of $\alpha_{j}$ and $\beta_{j}$ respectively. The $\hat{\alpha}_{j}$ and $\hat{\beta}_{j}$ were estimated over a period before the merger and thus did not include merger-specific effects.

The average abnormal return over all firms in event time (i.e. relative to the merger date) $\tau$ is defined as

$A A R_{\tau}=\frac{1}{n} \sum_{j=1}^{n} A R_{j}$

where $A A R_{\tau}=$ average abnormal return in event time period $\tau$ and $n=$ number of firms in the sample. These average abnormal returns are cumulated to yield the cumulative average abnormal returns:

$$
C A R_{p}=\underset{T=0}{p} A A R_{\tau}
$$

Where $C A R_{p}=$ the cumulative average abnormal returms up to time period $p$. If no unexpected price movements exist around the merger date then it can be expected that both the $A A R_{\text {r }}$ and $C A R_{p}$ will fluctuate randomly around 0 .

Bhana calculated cumulated average abnormal daily returns from a period 90 trading days before the merger announcement to 20 trading days after the merger announcement for a sample of $\mathbf{5 0}$ firms quoted on the JSE.

The methodology described above will indeed isolate any unusual or unexpected price fluctuations around the merger date, and this behaviour is clearly demonstrated by Bhana who showed that the $C A R_{p}$ for acquired firms increased steadily from a point $\mathbf{4 0}$ trading days prior to the merger announcement until some five trading days after the merger announcement. The increase in $C A R_{p}$ was most dramatic in the last 15 days before the merger announcement. Similar results were obtained by Affleck-Graves, Flach \& Jacobson (1988) on the JSE, who used weekly data and found that abnormal returns start accumulating to the acquired firms' shareholders some 10 weeks prior to the merger announcement.

Although it is not contested that insider trading activity does occur on the JSE and other world exchanges, Bhana's research does not satisfactorily prove that the abnomal returns earned by acquired firm's shareholders around the time of the merger announcement were caused by insider trading alone, or at all. It is reasonable to assume that the price adjustments prior to merger are a response to some publicly available information regarding the merging firms which improves the likelihood of a merger, and thus increases shareholders abnormal returms. Indeed, Affleck-Graves et al. (1988) are led to comment that 'while one is tempted to conclude that insider trading or information leakages are the cause, it is important to stress that this is in no way proved by the results presented here. Other rational explanations such as accurate appraisal by investment analysts and anticipation by the market cannot be ruled out'.

It is acknowledged that such eminent researchers 2 Mandelker (1974) and Keown \& Pinkerton (1981), who conducted similar studies of shareholder wealth gains around merger announcements on US markets, ako concluded that information leakages had led to the gain in abnormal returns to acquirer sharcholders. However, in their review paper on the scientific research into mergers and acquisitions, Jensen \& Ruback (1983) strongly criticize these conclusions. They stress that no teats are provided of the plausible alternative hypothesis mentioned earlier, i.e. that the unexpected price changes are unbiased responses to publicly available information which has increased the probability of a take-over. 
It is thus maintained that Bhana's empirical study does not prove that insider trading gives rise to the wealth gains which have accrued to acquired firms' shareholders, but merely provides a study of the unexpected returns around the merger announcement date, the cause of which cannot be determined.

\section{References}

Affleck-Graves, J.F., Flach, T.P. \& Jacobson, A.S. 1988. The Effect of Merger Announcements on the Share Prices of the Acquired and Acquiring Companies. S. Afr. J. Bus. Mgmt., vol.19, 147-154.

Bhana, N. 1987. Take-over anæouncements and insider trading activity on the Johannesburg Stock Exchange. S.Afr.J.Bus.Mgmt., vol. 18, 198-208.

Fama, E.F., Fisher, L., Jensen, M. \& Roll, R. 1969. The Adjustment of Stock Prices to New Information. Int. Econ. Rev., February 1969, 1-21.
Jensen, M.C. \& Ruback, R.S. 1983. The Market for Corporate Control - The Scientific Evidence. J. Fin. Econ., vol. 11, 5-50.

Keown, A.J. \& Pinkerton, J.M. 1981. Merger Announcements and Insider Trading Activity. An Empirical Investigation. J. Fin., vol. 36, 855-869.

Mandelker, G. 1974. Risk and Return: The Case of Merging Firms. J. Fin. Econ., vol. 1, 303-335.

Sharpe, W.F. 1963. A Simplified Model for Portfolio Analysis. Manage. Sci., vol. 9, 277-293.

\section{R.C. VAN DEN HONERT \& G.D.I. BARR}

Department of Mathematical Statistics, University of Cape Town, Private Bag, Rondebosch, 7700 Republic of South Africa 